\title{
Ageing Well Kia eke kairangi ki te taikaiamātuatanga: a National Science Challenge for New Zealand
}

The New Zealand National Science Challenges were launched in 2013 as new research funding initiatives to support high quality, mission-led science in the country. One of these Challenges, Ageing Well, has particular relevance for physiotherapy and involves physiotherapists in management and science leadership, as well as through its funded research programme.

\section{BACKGROUND: OUR AGING POPULATION}

People are living longer, a trend which has continued globally for at least a century. Such ageing is unprecedented historically, and will have profound effects over the coming decades: on countries, on communities, on families and whānau, and on individuals. These changes will affect all areas of our lives.

This global pattern is reflected in the ageing population in New Zealand, where our life expectancy at birth is now 83.2 years for females and 79.5 years for males; this has increased by 1.0 years for females and 1.5 years for males since 2005-07. However, there are disparities across the population. In particular, Māori men live almost 7 years less than other New Zealand men: life expectancy at birth is 73.0 years for Māori males, compared with 80.3 years for non-Māori males (Statistics New Zealand 2015).

\section{THE NEW ZEALAND NATIONAL SCIENCE CHALLENGES}

Based upon a nationwide public consultation in 2012-2013 and reports from Peak Panels comprising leading scientists in the country, the National Science Challenges were launched by the government (Ministry of Business, Innovation and Employment) as new restructured research funding agencies, starting in 2012-2013. There are now a total of 11 Challenges including areas as diverse as New Zealand's biological heritage (directed at 'protecting and managing our biodiversity, improving our biosecurity, and enhancing our resilience to harmful organisms') and Science for technological innovation ('Enhancing the capacity of New Zealand to use physical and engineering sciences for economic growth')(Ministry of Business, Employment and Innovation 2016).

The Challenges also comprise three which are particularly focused on health and wellbeing across the lifespan: A Better Start ('Improving the potential of young New Zealanders to have a healthy and successful life'), Healthier Lives ('Research to reduce the burden of major New Zealand health problems'), and Ageing Well ('Harnessing science to sustain health and wellbeing into the later years of life').

\section{AGEING WELL}

The Ageing Well National Science Challenge, Kia eke kairangi ki te taikaiamātuatanga, is based upon a nine partner collaboration, with University of Otago acting as the host institution; other institutions include universities such as University of Auckland and AUT University, as well as AgResearch (a Crown Research Institute) and CRESA (Centre for Research Evaluation and Social Assessment). The initial RFP
(Request for Proposals) from the Ministry in February 2014 highlighted three themes for research focus, as outlined below (Table 1) (Ministry of Business, Employment and Innovation 2014).

\section{Table 1: Ageing Well - Research Themes and Impacts}

\begin{tabular}{ll}
\hline Themes & Outcomes \\
\hline $\begin{array}{l}\text { Maintaining brain } \\
\text { health }\end{array}$ & $\begin{array}{l}\text { The number of older people requiring } \\
\text { residential care due to cognitive and } \\
\text { other neurodegenerative deficits, } \\
\text { including those resulting from strokes, } \\
\text { is reduced. }\end{array}$
\end{tabular}

Dealing with physical Older people maintain more frailty independent mobility later in life with reduced osteoarthritis and fracture rates, reduced hospital re-admissions, and increased physical activity.

Enhancing the role of older people in society

Older people have increased engagement and a sense that their roles and contributions are valued and supported within their culture and communities.

Like all Challenges, the fundamental difference between Ageing Well and other research funding agencies such as Health Research Council and Lottery Health, is that the research it funds is mission-led (cf researcher-initiated research). For Ageing Well, the defined mission is: to push back disability thresholds to enable all New Zealanders to reach their full potential through the life course with particular reference to the latter years of life. It should be noted that further extending lifespans is not a primary focus for research in this Challenge; rather the focus is on improving health and wellbeing: 'adding life to years, rather than years to life'.

The Challenge was awarded a total of \$14.6 million in 2015, based upon an agreed Research and Business Plan (Ageing Well Research and Business 2015), to cover a five year funding window ('tranche') until June 2019. The importance of this (and the funds provided for the other 'health' Challenges) is that it represents new research funds and opportunities for research in health and wellbeing. Furthermore, as with other Challenges, it is planned that a second 5 year tranche of funding will be available from 2019-2024. A significant proportion of the first tranche funding has already been allocated to research projects (see Table 2). Furthermore, the Challenge has set aside some $\$ 3.5$ million for a contestable project round during 2016, which is currently being pursued in collaboration with Health Research Council, and Ministry of Health. Within this open round it is anticipated that there will be dedicated funds to support Māori researchers and research associated with the Ministry of Health's Mobility Action Programmes. 
Table 2: NSC Ageing Well - Core Funded Research Projects (Ageing Well 2015)

\begin{tabular}{ll}
\hline Research Project Title & Lead Investigator(s) \\
\hline $\begin{array}{l}\text { Enabling older people's independence, active lives and } \\
\text { participation in the face of structural housing tenure } \\
\text { changes and reliance on rental housing }\end{array}$ & K. Saville-Smith (CRESA) and colleague \\
$\begin{array}{l}\text { Transforming ways of living and reducing frailty* } \\
\text { Social isolation and loneliness amongst older people within } \\
\text { the multicultural New Zealand context: implications for }\end{array}$ & R. Teh (Auckland) and colleagues
\end{tabular}

ageing in place and service delivery

Can neurodegenerative end of life care be improved with individualised interventions?

Older people in retirement villages: unidentified need and intervention research

Risk factors for reduced social engagement in older people

Evaluation of the Drug Burden Index to predict adverse outcomes in older people

Health and Wellness Coaching (HWC) for primary stroke and CVD prevention: an RCT

M. Boyd (Auckland) and colleagues

M. Connolly (Waitemata DHB and Auckland) and colleagues

H. Jamieson and S. Keeling (Otago, Christchurch)

H. Jamieson (Otago, Christchurch)

V. Feigin (AUT) and colleagues

Implanted electrical stimulators to augment stroke recovery*

J. Reynolds (Otago) and colleagues

Notes: *; include physiotherapy researchers

\section{RELEVANCE FOR PHYSIOTHERAPY}

Table 2 highlights several key areas of interest to physiotherapists. While several of the projects presented in the table include the active involvement of physiotherapy researchers as co-investigator (denoted *), it can be seen from the titles that most have direct relevance to - and will undoubtedly have impact for - physiotherapy research and practice, now and into the future.

In addition, with the forthcoming Challenge contestable round, there will be further opportunities for physiotherapists to become involved and contribute to the work of the Challenge, as members of research teams, co-investigators, or as principal investigators.

New Zealand is already recognised for high quality research in the area of ageing, including pioneering research on falls prevention (Campbell et al 1999); a significant proportion of this research has involved or been led by physiotherapists (Hale et al 2012, Sullivan et al 2014, Taylor et al 2012, Wagenaar et al 2012). As the programme of research funded by Ageing Well continues to grow and develop, it is hoped that there will be similar opportunities for engagement by physiotherapy researchers, working with multidisciplinary research teams, to help push back the disability thresholds for all New Zealanders. This is important, as physiotherapists because of their background, skills and training can bring a unique perspective to the work of the Challenge.
Professor G David Baxter TD, DPhil, MBA, BSC (Hons) Director, National Science Challenge for Ageing Well School of Physiotherapy, University of Otago

doi: 10.15619/NZJP/44.1.01

\section{ADDRESS FOR CORRESPONDENCE}

Professor David Baxter, School of Physiotherapy,

University of Otago, PO Box 56, Dunedin,

Telephone 03479 7411. Email: david.baxter@otago.ac.nz

\section{REFERENCES}

Ageing Well Research and Business (2015). Retrieved from: https://www. ageingwellchallenge.co.nz/wp-content/uploads/2015/10/Research-andBusiness-Plans.pdf [Accessed February 25, 2016].

Ageing Well website (2016) www.ageingwellchallenge.co.nz [Accessed February 25, 2016]

Campbell AJ, Robertson MC, Gardner MM, Norton RN, Buchner DM (1999) Falls prevention over 2 years: a randomized controlled trial in women 80 years and older. Age Ageing 28 (6): 513-518.

Hale LA, Waters D, Herbison P (2012) A randomized controlled trial to investigate the effects of water-based exercise to improve falls risk and physical function in older adults with lower-extremity osteoarthritis. Archives of Physical Medicine and Rehabilitation 93 (1): 27-34. doi. org/10.1016/j.apmr.2011.08.004.

Ministry of Business, Employment and Innovation (2014). Retrieved from: http://www.mbie.govt.nz/info-services/science-innovation/national-sciencechallenges/documents-image-library/key-documents/nsc-rfp-2nd-tranchefeb-2014.pdf [Accessed February 25, 2016]. 
Ministry of Business, Employment and Innovation (2016). Retrieved from: http://www.mbie.govt.nz/info-services/science-innovation/national-sciencechallenges [Accessed February 25, 2016].

Statistics New Zealand (2015). Retrieved from: http://www.stats.govt.nz/ browse_for_stats/health/life_expectancy/NZLifeTables_HOTP12-14.aspx [Accessed February 25, 2016].

Sullivan SJ, La Grow S, Alla S, Schneiders AG (2014) Riding into the future: a snapshot of elderly mobility scooter riders and how they use their scooters. New Zealand Medical Journal 127 (1402): 43-49.

Taylor L, Lewis GN, Taylor D (2012) Short-term effects of electrical stimulation and voluntary activity on corticomotor excitability in healthy individuals and people with stroke. Journal of Clinical Neurophysiology 29 (3): 237 243. doi: 10.1097NNP.0b013e3182570f17.

Wagenaar R, Keogh JW, Taylor D (2012) Development of a clinical MultipleLunge Test to predict falls in older adults. Archives of Physical Medicine and Rehabilitation 93 (3): 458-465. doi: 10.1016/j.apmr.2011.08.044. 